\title{
Enhancement Strategies for Classroom Teaching Effect of Professional Art Education
}

\author{
https://doi.org/10.3991/ijet.v16i06.21091 \\ Nan Li \\ College of Art and Design, Huanghuai University, Zhumadian, China \\ gu1991rong@163.com
}

\begin{abstract}
In professional art education, it is a great challenge to improve the classroom teaching effect. To cope with the challenge, this paper identifies the factors affecting the classroom teaching effect of professional art education from the perspective of teachers and that of students, through multi-perspective analysis. In the context of professional art education, the connotations of enhancing the classroom teaching effect were fully analyzed. On this basis, several strategies were put forward to enhance the said effect in professional art education. In addition, multi-angled measurement index systems were established for the enhancement, and a measurement model for the said effect was created through multi-factor decision-making. The research findings provide strong practical and theoretical supports to improving the classroom teaching effect of professional art education.
\end{abstract}

Keywords-Professional art education, classroom teaching, teaching effect, grey relational analysis (GRA), strategy analysis

\section{Introduction}

Classroom teaching has always been the most important link in education, and it is the main venue for the transfer of professional knowledge to students; the classroom teaching activities and effects are the key factors for the promotion of classroom teaching quality and student learning ability [1-3], therefore, modern educators and pedagogical scholars have laid their eyes on the problem of classroom teaching effect enhancement and they have conducted various research on the said problem [4-5].

Professional art education is an important part of modern education, it not only plays a positive role in promoting the comprehensive quality of students, but also has indispensable effects on the cultivation of art professionals [6-8]. To ensure the cultivation quality of art professionals and improve the comprehensive quality of students, we need to lay emphasis on the classroom teaching of professional art education, and take practical measures to enhance the classroom teaching effect of professional art education.

To this end, scholars have carried out a series of research on the said subject, for instance, with a teaching reform program of basic course of painting colors of art major in a college as an example, Jin [9] analyzed the classroom teaching methods 
and learning methods of professional art education. Chen [10] took the art education major in Tibetan classes in the mainland as an example to discuss the preparation works, implementation strategies and evaluation methods of classroom teaching. Sawyer [11] systematically reviewed literatures concerning the topic of creative teaching in art design and provided a reference for the classroom teaching of professional art education. Liang and $\mathrm{Li}$ [12] analyzed the current situation of professional art education in colleges and universities in a certain area, and summarized the existing problems and proposed the corresponding teaching implementation strategies. $\mathrm{Xi}$ [13] analyzed the state quo of classroom teaching of professional art education in colleges and universities in the context of "Internet+", and discussed the corresponding implementation strategies.

All above-mentioned research results facilitate the promotion of classroom teaching effect of professional art education, and they provide very good references for carrying out efforts to promote such effect. However, since the professional art education is a constant developing process, many dynamic factors would affect the classroom teaching effect of professional art education; especially, the particular features of art education have doomed that the promotion of classroom teaching effect must comprehensively consider constraints of various aspects. Classroom teaching effect enhancement is a very complicated systematic project, and it still have much room for further analysis and research. For this reason, based on the existing research results, this paper aims to further discuss the strategies and methods for enhancing the classroom teaching effect of professional art education.

The content of this paper is divided into 6 parts: the first part gives an overview of relevant research results and discusses problems existing in current professional art education. The second part analyzes factors affecting the classroom teaching effect of professional art education from the perspective of teachers. The third part analyzes the same problem discussed in the second part but from the perspective of students. The fourth part researches the strategies and means to improve the classroom teaching effect of professional art education. The fifth part proposes an improved model for the measurement of the classroom teaching effect of professional art education, and it also gives the corresponding index systems. The sixth part is the conclusion.

\section{Influencing Factors of Classroom Teaching Effect of Professional Art Education from the Perspective of Teachers}

Influencing factors of classroom teaching effect of professional art education from the perspective of teachers (hereinafter referred to as: teacher-angle factors) refer to the related factors that restrict the enhancement of the classroom teaching effect of professional art education when we view the problem from the angle of art educators, and these teacher-angle factors mainly reflect the internal reasons and potential constraints of knowledge "teaching" in the process of professional art education. The teacher-angle factors are: 


\subsection{Teaching philosophy}

The teaching philosophy of the classroom teaching of professional art education is the cognition of professional art teachers towards the essential problems of art teaching, it is their basic beliefs when they engage in classroom teaching activities, it is reflected in their attitudes, opinions and concepts during art teaching, and it is also shown in the actual operation and implementation of art teaching activities. Professional art education has very particular professional features, this subject requires art teachers to have not only certain academic attainments in art, but also proactive teaching ideas. Art teachers should have a correct teaching attitude, and should be able to formulate development strategies for the classroom teaching of professional art education from the perspective of art talents cultivation, and they should be able to improve the teaching system of professional art courses from a developmental perspective; therefore, during art teaching, professional art teachers should pay attention to not only the teaching efficiency and working efficiency of art courses, but also the learning status of art students; moreover, professional art teachers must have an overall concept of teaching and learning, as well as the "versatile talents" cultivation concept. In the meantime, professional art teachers should be able to advance with the times and perfect their personal teaching qualities constantly, and reflect upon their teaching activities and results, and thus forming a set of effective teaching strategies of professional art education. However, in the implementation process of professional art courses, there are factors with commercial characteristics, and such profit-seeking atmosphere makes some professional art teachers pursue the commercial interests over the essential content of art education. Therefore, to improve the classroom teaching effect of professional art education, an upright teaching philosophy is a necessity.

\subsection{Teaching method}

Art education is quite different from science and engineering education, besides instilling professional art knowledge, it lays more emphasis on practice. In art education, practice is closely related to theoretical learning, but meanwhile, since art creation requires inspiration, it must also pay attention to the cultivation of art majors' innovative thinking. Obviously, the cultivation of art majors is a complex talent training project, and this requires the teaching method of professional art education to be applicable and adaptable. However, due to the different development environment of the times, the different social and cultural backgrounds, and the different teaching perspectives, art teachers would have different understandings of the teaching methods, and how would they apply these teaching methods to cultivate high-quality art talents is very important for professional art education. In essence, firstly, the classroom teaching method should serve the teaching goals of professional art education, and be able to meet the training objectives of art professionals and the requirements of the teaching tasks of professional art education; secondly, the application of the teaching method should be able to reflect the values of art education and the behavioral relationship between teachers and students in art teaching activities; thirdly, the teaching method should take into account the influence and constraints of various aspects 
such as the teaching content, teaching organization forms, and teaching planning, etc. Thus, we can see that, only by integrating various teaching factors and choosing suitable teaching method, can the teaching method better fit the classroom teaching of professional art education, and thereby better enhancing the classroom teaching effect. However, in the current professional art education, the classroom teaching methods are generally too simple and not as varied, they haven't considered the learning status of art students, which has certain impact on the classroom teaching effect of professional art education.

\subsection{Teaching content}

According to previous discussion, the classroom teaching of professional art education should pay attention to not only the theoretical learning and practice, but also their intrinsic essential relationship, and this requires to combine with the course teaching development plans of professional art education to reasonably formulate teaching content of the art courses during the implementation of professional art education. In terms of art talent cultivation, the teaching content of art courses is the professional knowledge of art major taught by art teachers and the teaching information received by art students during the learning of art courses. Under normal circumstances, teaching content is reflected in many aspects such as the teaching standards, textbooks, and teaching plans; and the content mostly comes from the art courses, art textbooks, and art teaching activities, etc. In term of content form, on the one hand, the teaching of art course content requires teachers and students to reasonably use the textbooks and properly select, analyze, screen, process, and reform the teaching content through teaching plan verification and teaching activity demonstration; on the other hand, it also requires the teachers to scientifically and rationally summarize, process and organize the textbooks and teaching plans, and give proper guidance to students during art course content teaching, so that teacher-student interactions during art course teaching could transfer the information more effectively and thus better serve the classroom teaching of professional art education. However, judging from the current teaching content of art professional education, there are still some problems with it; first, the teaching content is outdated, and the textbooks of some courses have not been updated for years; second, the course content lacks contemporary characteristics, it is out of touch with the development of the times; third, insufficient integration of the theory and practice, and inadequate comprehensive education; fourth, the mismatch of teaching content and student training, and students are less interested in learning. Therefore, to improve the classroom teaching effect of professional art education, well designing the teaching content is also an important factor.

\subsection{Teaching tool}

Teaching tools are the appliances to transmit the teaching content of the courses, they are indispensable for course content teaching and learning. With the rapid development of modern science and technology and the extensive application of modern intelligent education technologies, intelligent teaching modes have become more and 
more important. In the case of art education, its particular professional features also require to use these intelligent technologies and modern teaching tools to support its teaching activities. In traditional classrooms, the teaching is often carried out by the means of oral lecturing, paper textbooks reading, and chalk and blackboards; and these are indeed good ways for teachers and students to communicate face to face, and teaching of art knowledge could better fit the students' learning status; however, as professional art education is developing continuously with the times, the information volume is growing explosively and so is the knowledge of art education; moreover, with the acceleration of the development pace of modern society, the demand for art professionals in various industries in the society has become more and more urgent, and the traditional teaching tools can no longer meet the demand growth for the art professionals. Different from traditional classroom teaching, the modern intelligent teaching tools mainly use the advanced intelligent technologies and equipment to provide support for classroom teaching. During the implementation of teaching activities, the teaching content is intuitively displayed and shown to students via sound, images, light and electricity, which is more conducive for students to absorb the professional art knowledge. In particular, with the increase in the demand for modern talents, intelligent education has a better development foundation, and research findings of scientists suggest that, students' sense of hearing, vision, touch, smell, and taste are all helpful to knowledge receiving, and this conclusion is especially meaningful for professional art education; since the professional art knowledge has diversified forms, the teaching content can be more abstract, therefore, it is even more necessary to use modern intelligent technologies and equipment in art teaching. It can be seen that the application of intelligent teaching tools is an inevitable trend for modern art education. Paying attention to the comprehensive application of intelligent teaching tools in art education and integrating them into the classroom teaching activities can effectively enhance the classroom teaching effect of professional art education.

\section{Influencing Factors of Classroom Teaching Effect of Professional Art Education from the Perspective of Students}

Influencing factors of classroom teaching effect of professional art education from the perspective of students (hereinafter referred to as: student-angle factors) refer to the related factors restricting the enhancement of classroom teaching effect of professional art education from the perspective of art learners, and these student-angle factors mainly reflect the internal reasons and potential constraints of knowledge "learning" in the process of professional art education. The student-angle factors are:

\subsection{Knowledge foundation}

Besides professional art courses, art major students also need to study cultural courses. However, in the college enrollment tests, compared with science and engineering majors, the requirement of cultural course scores for art majors is lower, 
which has resulted in that some art students have better performance in art courses while their cultural course performance is not satisfactory, and this situation would cause a few problems: first, a weak knowledge foundation would affect art students' comprehension ability in learning art knowledge and understanding deeper level academic issues, and art students with a poor knowledge reserve can hardly understand the essential content of art; second, for art students with a weak knowledge foundation, the art works they create often do not have profound meanings; besides inspiration, art creation also attaches great importance to the cultural and knowledge reserve, which will bring inexhaustible materials and endless power for art creation, and it is just an important guarantee for artistic innovation; third, a poor knowledge foundation will narrow down the professional vision of art majors, in terms of art work appreciation, high professional level art work creation requires the creators to have a broad professional vision, without enough knowledge reserve, art professionals can hardly achieve such creation or appreciation level.

\subsection{Enthusiasm and interest in art learning}

Professional art education has very special professional characteristics, which require art students to stay focus during learning, and the art learning is a continuous process. In the early stage of art learning, students are generally in a passive state, regardless of basic professional courses or the practical sketching courses, their learning tasks are relatively heavy, and their mental pressure is relatively high. Then, after art students have passed the entrance exams and entered the college, they tend to relax in their studies, and their enthusiasm and interest in learning will change greatly. Some art students may lower their own learning standards, they are no longer serious in learning preparation, and some cannot maintain a correct learning attitude; then in art courses, they cannot well absorb or digest the course content taught by teachers, and thus their learning effect would be greatly affected.

\subsection{Learning depth}

With the continuous deepening of professional art education, the course content is getting richer, including not only the basic art knowledge and common general knowledge, but also numerous professional art knowledge; moreover, as disciplines are integrating, the interdisciplinary professional knowledge has also become an important factor in the cultivation of high-level art professionals. The various learning contents are cumulating, without a complete and reasonable learning plan and learning system, students would be exhausted to cope with the massive knowledge points, their learning can only stay at a superficial level, and they cannot dive into deeper learning level, resulting in that the classroom learning of art majors lack the learning depth, and the classroom teaching effect is compromised. 


\subsection{Learning initiative and creativity}

Above analysis shows that the teaching content of professional art education includes multiple aspects such as theoretical knowledge learning, practical knowledge learning and professional skills learning, in addition, they also need to learn the knowledge of some interdisciplinary courses. However, too much pure knowledge learning would limit students to knowledge within the courses, while ignoring the extended knowledge outside the courses. Moreover, in the learning process of art courses, unlike students in science and engineering majors, art majors often do not have a good logic analysis ability, and they generally lack systematic thinking training, as a result, their innovative thinking ability has certain limitation, and their creativity cannot be reflected in their art works. In addition, due to the large amount of learning content of art courses and the heavy learning tasks, art majors are often in a passive learning state, their learning initiative is not good, and they do not treat art course learning with an active learning attitude. The lack of learning initiative and creativity would affect art majors' cognition and understanding of course knowledge, and thus adversely affecting the classroom teaching effect of professional art education.

\section{Strategies to Enhance Classroom Teaching Effect of Professional art Education}

\subsection{Formulate reasonable teaching goals}

The classroom teaching of professional art education should be consistent with the teaching goals of art talent cultivation, and it must serve the said teaching goals. To formulate reasonable teaching goals, multiple aspects should be taken into consideration, and this paper proposes four aspects: first, the social needs, the teaching goals should be formulated based on the demands of social development for art professionals; second, competitiveness of the art school and its rank, the formulation of teaching goals should consider the social competitiveness of the professional art school and its comprehensive rank in the field; third, the source of students, the formulation of teaching goals should also consider the conditions of the students sources, so that the formulated teaching goals are targeted; fourth, the contemporary feature of talent cultivation, that is, the formulation of teaching goals should take the contemporary feature of art talent cultivation into consideration, so that the formulated teaching goals can develop sustainably.

\subsection{Improve the curriculum system}

A complete curriculum system is the basic condition for the enhancement of the classroom teaching effect of professional art education, it is not only the knowledge source of art talent cultivation, but also the development guidance for art talent cultivation. Therefore, the construction of the curriculum system is a primary condition for 
the teaching activities of professional art education. This paper proposes that, to improve the curriculum system of professional art education, the following aspects should be noticed: first, well plan the professional courses of art major; second, well design the textbooks of art major; third, well devise excellent courses of art major; fourth, well construct modern teaching bases for professional art education.

\subsection{Improve the vocational skills of art faculty}

The level of art teachers' vocational skills is an important measure for the teaching level of professional art courses. Under normal circumstances, the higher the level of art teachers' vocational skills, the higher the possibility of cultivating high-level art professionals. On the contrary, art teachers with poor vocational skills can hardly cultivate qualified art professionals. Teachers with good vocational skills can fully impart the teaching content of art courses in classroom teaching, and they can expand art students' learning vision using their own professional skills, so that the art students could better absorb the content they learnt in the class. To improve the vocational skills of art faculty, art schools can introduce advanced art teaching talents to join the art faculty, or they can choose to cultivate their own art teaching talents by providing internal training programs for teachers or by the self-training of teachers, so that the professional art teachers could continuously strengthen their vocational skills, and thereby forming a competitive art faculty with excellent vocational skills.

\subsection{Use intelligent teaching tools}

Art education is an indispensable part of modern education. With the extensive application of intelligent technologies in modern education, the classroom teaching of professional art education should also pay attention to the use of intelligent teaching tools. Especially as AI (artificial intelligence) is developing constantly, its application in modern education has become a mainstream teaching method. However, using intelligent teaching tools in art teaching doesn't mean that we'll have to drop all the traditional teaching means. Both the traditional and modern teaching tools have their respective advantages and disadvantages. The traditional means can better promote the interaction and communication between teachers and students, which is more conducive to reflect the emotions, personalities, and aesthetic charms of the professional art teachers; while the modern means can impart professional knowledge of art major in a more effective way, and they can greatly promote the cultivation of art students' creativity and professional skills, and improve their learning efficiency and quality. Therefore, the use of intelligent teaching tools requires to organically integrate the traditional teaching means with the modern intelligent teaching tools.

\subsection{Improve the teaching management system}

A good teaching management system is an important guarantee for orderly carrying out classroom teaching activities of professional art education, and it also points out the right direction for it. Therefore, improving the teaching management system 
has a promotive role in organizing and implementing the classroom teaching activities of professional art education. This paper proposes that, to improve the teaching management system, the following three aspects need our attention: first, well formulate rules and regulations for material, financial and manpower resources that are required in the process of professional art education; second, well plan the implementation details of the teaching activities and well manage the teaching performance; third, well design the student management details and well formulate the learning reward and punishment mechanism of students.

\subsection{Use diversiform teaching methods}

One single teaching method can no longer satisfy the requirements of modern education, especially for professional courses like the art courses, which are highly professional, rich in teaching content, highly practical and highly integrated, therefore, multiple teaching methods are required to carry out diversiform art teaching activities and give demonstrations for different teaching content in a targeted manner; also, we should combine with the real situations in art course teaching and the individual needs of art students to teach them in accordance of their aptitude, so that the adaptability of the teaching methods would be even better. Moreover, how art teachers apply these diversiform teaching methods in their art courses? This paper proposes that, on the one hand, it is necessary to enhance the awareness of art teachers to conduct intelligent teaching and avoid just simply repeating what the textbook says; on the other hand, it is necessary to adopt measures to enhance the adaptability of art teaching, such as organize art teachers to learn the theories of art teaching, give demonstrations of professional art teaching methods to art teachers, arrange them to visit famous art teachers, and hold various art teaching competitions, etc.

\subsection{Activate classroom learning atmosphere and interaction}

Activating the classroom learning atmosphere and interaction is a catalyst for enhancing the classroom teaching effect of professional art education. A good classroom learning atmosphere can well enhance students' learning initiative and interest, making them absorb new knowledge in the classroom more easily, and this is also helpful for art students to think about deeper level aesthetic questions. Moreover, activating classroom interaction makes it easier for art students to concentrate on classroom learning, so that they can follow the teaching ideas of professional art teachers to conduct art learning, and find out the problems in learning more easily. Art teachers can use some "teaching tricks" such as case analysis, themed stories, Q\&A, and enlightening talks in the classroom teaching to activate classroom learning atmosphere and interaction of art courses. 


\section{Measurement Index Systems for Classroom Teaching Effect of Professional Art Education}

\subsection{Methods}

To measure the classroom teaching effect of professional art education, this study adopted a series of research methods such as questionnaire survey, data review, statistical analysis, and qualitative and quantitative analysis. Wherein the questionnaire survey and data review obtained the measurement indexes of the said effect for us by investigating art educators in the field; the statistical analysis obtained the data of the measurement indexes for us; and the qualitative and quantitative analysis were used to help construct the measurement model for the classroom teaching effect of professional art education.

\subsection{Selection of measurement indexes}

The selection of measurement indexes should follow the scientific principle, objective principle, pertinent principle, comprehensive principle, and quantifiable principle. The scientific principle means that the selected measurement indexes must have clear scientific meanings. The objective principle means that the selected measurement indexes must be based on objective facts. The pertinent principle means that the selected measurement indexes should be representative and typical. The comprehensive principle means that the selected measurement indexes should be able to reflect the various levels and aspects of the classroom teaching effect of professional art education. The quantifiable principle means that the selected measurement indexes should be easily quantified.

\subsection{Specific content of measurement indexes}

According to above analysis, the enhancement of classroom teaching effect of professional art education should be viewed from two angles, the teachers, and the students.

The teacher-angle factors include the content as shown in Table 1 below: 
Table 1. The teacher-angle measurement index system

\begin{tabular}{|c|c|c|}
\hline System layer & First-level index & Second-level index \\
\hline \multirow{17}{*}{$\begin{array}{l}\text { The teacher-angle } \\
\text { measurement } \\
\text { index system }\end{array}$} & \multirow{5}{*}{ Classroom teaching content } & Teaching content matches the syllabus \\
\hline & & Teaching content is consistent with teaching progress \\
\hline & & Teaching content matches the textbooks \\
\hline & & Teaching content is rich and diverse \\
\hline & & Teaching content is up-to-date \\
\hline & \multirow{6}{*}{ Classroom teaching method } & Teaching method is advanced \\
\hline & & The use of teaching tools is reasonable \\
\hline & & Knowledge points are highlighted \\
\hline & & Teaching method is flexible and individualized \\
\hline & & $\begin{array}{l}\text { Teaching method can trigger students' interest in learn- } \\
\text { ing }\end{array}$ \\
\hline & & Teaching method is scientific \\
\hline & \multirow{6}{*}{$\begin{array}{l}\text { Classroom teaching perfor- } \\
\text { mance }\end{array}$} & Advanced teaching ideas \\
\hline & & Classroom teaching reform ability \\
\hline & & Classroom teaching atmosphere and environment \\
\hline & & Classroom teaching is interactive \\
\hline & & Classroom teaching is organized \\
\hline & & Completion of classroom tasks \\
\hline
\end{tabular}

The teacher-angle factors include the content as shown in Table 2 below:

Table 2. The student-angle measurement index system

\begin{tabular}{|c|c|c|}
\hline System layer & First-level index & Second-level index \\
\hline \multirow{12}{*}{$\begin{array}{l}\text { The student-angle meas- } \\
\text { urement index system }\end{array}$} & \multirow{5}{*}{$\begin{array}{l}\text { Classroom learning content } \\
\text { absorption }\end{array}$} & Mastery of professional knowledge points \\
\hline & & Professional knowledge extension \\
\hline & & Classroom learning participation \\
\hline & & Classroom learning interest \\
\hline & & Classroom learning concentration \\
\hline & \multirow{7}{*}{$\begin{array}{l}\text { Classroom learning perfor- } \\
\text { mance }\end{array}$} & Pass rate \\
\hline & & Excellent rate \\
\hline & & Mastery of professional skills \\
\hline & & Improvement of autonomous learning ability \\
\hline & & Learning creativity \\
\hline & & Learning adaptability \\
\hline & & Learning coordination ability \\
\hline
\end{tabular}

\subsection{Processing of measurement indexes}

Based the obtained measurement indexes, the initial data of different measurement indexes of each measurement object were obtained through data sorting and statistical analysis. Since different indexes have different types and dimensions, they need to be normalized to have a unified measurement standard. Assume there're M objects and $\mathrm{N}$ indexes, then the initial value of the $i$-th object with respect to the $j$-th index is: $G(i j)=\left[g^{a}(i j), g^{b}(i j)\right], g^{a}(i j) \leq g^{b}(i j)$. 
If, for the $j$-th index, the greater the value, the better, then the corresponding normalized value is: $V(i j)=\left[v^{a}(i j), v^{b}(i j)\right], v^{a}(i j) \leq v^{b}(i j)$.

where,

$$
\begin{gathered}
v^{a}(i j)=\frac{g^{a}(i j)-\min _{1 \leq i \leq M} g^{a}(i j)}{\max _{1 \leq i \leq M} g^{b}(i j)-\min _{1 \leq i \leq M} g^{a}(i j)} \\
v^{b}(i j)=\frac{g^{b}(i j)-\min _{1 \leq i \leq M} g^{a}(i j)}{\max _{1 \leq i \leq M} g^{b}(i j)-\min _{1 \leq i \leq M} g^{a}(i j)}
\end{gathered}
$$

If, for the $j$-th index, the smaller the value, the better, then the corresponding normalized value is: $V(i j)=\left[v^{a}(i j), v^{b}(i j)\right], v^{a}(i j) \leq v^{b}(i j)$.

where,

$$
\begin{gathered}
v^{a}(i j)=\frac{\max _{1 \leq i \leq M} g^{b}(i j)-g^{b}(i j)}{\max _{1 \leq i \leq M} g^{b}(i j)-\min _{1 \leq i \leq M} g^{a}(i j)} \\
v^{b}(i j)=\frac{\max _{1 \leq i \leq M} g^{b}(i j)-g^{a}(i j)}{\max _{1 \leq i \leq M} g^{b}(i j)-\min _{1 \leq i \leq M} g^{a}(i j)}
\end{gathered}
$$

In order to be able to distinguish the importance of different indexes, AHP [14-18] was adopted to assign weight values to the indexes:

First, the expert scoring method was applied to compare indexes in pairs and obtain the judgement value $r_{k j}$, the specific scoring standards are shown in Table 3.

Table 3. Scoring standards of $r_{k l}$

\begin{tabular}{|c|l|}
\hline$r_{k j}$ value & \\
\hline 1 & Indexes $\mathrm{k}$ and $\mathrm{j}$ are equally important \\
\hline 3 & Index $\mathrm{k}$ is slightly more important than index $\mathrm{j}$ \\
\hline 5 & Index $\mathrm{k}$ is more important than index $\mathrm{j}$ \\
\hline 7 & Index $\mathrm{k}$ is much more important than index $\mathrm{j}$ \\
\hline 9 & Index $\mathrm{k}$ is extremely more important than index $\mathrm{j}$ \\
\hline $2,4,6,8$ & The relatively importance of index $\mathrm{k}$ with respect to index $\mathrm{j}$ is between two adjacent states \\
\hline$r_{k j}=1 / r_{j k}$ & Relative important of index $\mathrm{j}$ with respect to index $\mathrm{k}$ \\
\hline
\end{tabular}

Then, after indexes were compared in pairs and all judgement values had been obtained, we can get the judgement matrix $\boldsymbol{R}$ as: 


$$
\boldsymbol{R}=\left[\begin{array}{ccccc}
r_{11} & \cdots & r_{1 j} & \cdots & r_{1 n} \\
\vdots & \vdots & \vdots & \vdots & \vdots \\
r_{k 1} & \cdots & r_{k j} & \cdots & r_{k n} \\
\vdots & \vdots & \vdots & \vdots & \vdots \\
r_{n 1} & \cdots & r_{n j} & \cdots & r_{n n}
\end{array}\right]
$$

Then, we can get the consistency index $C I(\boldsymbol{R})$ of judgement matrix $\boldsymbol{R}$ as:

$$
C I(\boldsymbol{R})=\frac{\lambda_{\max }(\boldsymbol{R})-n}{n-1}
$$

where, $\lambda_{\max }(R)$ represents the largest eigenvalue of judgement matrix $\boldsymbol{R}$.

By looking up tables, the value of the random consistency index $R I(\boldsymbol{R})$ could be obtained, then on this basis, the calculation model of consistency coefficient $C R(\boldsymbol{R})$ could be constructed as:

$$
C R(\boldsymbol{R})=C I(\boldsymbol{R}) / R I(\boldsymbol{R})
$$

If there is: $C R(\boldsymbol{R})<0.1$.

It indicates that the consistency of the judgement matrix $\boldsymbol{R}$ satisfies the requirement, then the weight of the $j$-th measurement index is:

$$
w_{j}=\sum_{k=1}^{n} r_{k j} / \sum_{k=1}^{n} \sum_{j=1}^{n} r_{k j}
$$

If $C R(\boldsymbol{R})<0.1$ is not satisfied, it means that the consistency of the judgement matrix $\boldsymbol{R}$ does not meet the requirement, and matrix $\boldsymbol{R}$ needs to be evaluated and analyzed again until its consistency meets the requirement.

\subsection{Establishment of measurement model}

After the measurement indexes were obtained, then, for the i-th measurement object, its gray comparison sequence $\boldsymbol{V}_{i}$ with respect to the measurement indexes is:

$$
\mathbf{V}_{i}=\{V(i 1), \cdots, V(i j), \cdots, V(i N)\}
$$

At the same time, the maximum value of the $j$-th index can be obtained as $V(j)=$ $\left[v^{a}(j), v^{b}(j)\right], v^{a}(j) \leq v^{b}(j)$.

$$
\left\{\begin{array}{l}
v^{a}(j)=\max _{1 \leq I \leq M} v^{a}(i j) \\
v^{b}(j)=\max _{1 \leq i \leq M} v^{b}(i j)
\end{array}\right.
$$


As a result, for the $M$ measurement objects, their gray reference sequence $\mathbf{V}$ with respect to the measurement indexes is:

$$
\mathbf{V}=\{V(1), \cdots, V(j), \cdots, V(N)\}
$$

According to the fuzzy theory [19-20], the Hamming distance between $\boldsymbol{V}_{\boldsymbol{i}}$ and $\boldsymbol{V}$ with respect to the $j$-th index is:

$$
D H(i j)=\frac{\left|v^{a}(j)-v^{a}(i j)\right|+\left|v^{b}(j)-v^{b}(i j)\right|}{2}
$$

Minimizing $D H(i j)$ with respect to both $i$ and $\mathrm{j}$, then there is:

$$
\Delta(D H(i j))=\min _{i} \min _{j} D H(i j)
$$

Maximizing $D H(i j)$ with respect to both $i$ and $\mathrm{j}$, then there is:

$$
\nabla(D H(i j))=\max _{i} \max _{j} D H(i j)
$$

According to the gray relational analysis (GRA) [21-25], the grey relational coefficient $\xi(i j)$ of $\boldsymbol{V}_{\boldsymbol{i}}$ and $\boldsymbol{V}$ with respect to the $j$-th index is:

$$
\xi(i j)=\frac{\Delta(D H(i j))+\beta * \nabla(D H(i j))}{D H(i j)+\beta * \nabla(D H(i j))}
$$

where, $\beta$ is the identification coefficient, its value generally takes $\beta=0.5$.

Based on the obtained weight value $w_{j}$ of the $j$-th measurement index, and the weighted gray relational degree $\psi(i)$ of all measurement indexes is:

$$
\psi(i)=\sum_{j=1}^{N}\left(w_{j} \times \xi(i j)\right)
$$

According to the theory of GRA, greater $\psi(i)$ value indicates that the $i$-th measurement object's classroom teaching effect of professional art education is better.

\section{Conclusion}

This paper discussed the enhancement of the classroom teaching effect of professional art education, and it had completed the following works:

1. From both the perspectives of teachers and students, this paper analyzed problems existing in the current classroom teaching of professional art education and the factors that can affect the teaching effect of art courses. 
2. This paper gave systematic analysis from multiple aspects and proposed strategies to enhance the classroom teaching effect of professional art education, which provided a good reference for the said matter.

3. This paper also constructed a multi-factor measurement model for the classroom teaching effect of professional art education, which pointed out a way for the quantitative analysis of the said effect.

\section{$7 \quad$ References}

[1] Sun, L. (2018). Research on the design of classroom teaching under the background of higher education reform. Brand, 2018(6): 231-232. https://doi.org/10.3969/j.issn.16711009.2018.06.137

[2] He, G. (2020). Schema interaction visual teaching based on smart classroom environment in art course, International Journal of Emerging Technologies in Learning, 15(17): 252267. https://doi.org/10.3991/ijet.v15i17.16441

[3] de Arriba, R., Vidagañ, M. (2020). Sharing drawings with smartphones in the classroom: Art-based education in social sciences, International Journal of Emerging Technologies in Learning, 15(15): 229-236. https://doi.org/10.3991/ijet.v15i15.14259

[4] Vásquez, N., Contreras, I., Solís, M.C., Nuñez, C., Rittershaussen, S. (2017). An analysis of teaching practices among newly qualified teachers working in diverse classrooms. Procedia-Social and Behavioral Sciences, 237: 626-632. https://doi.org/10.1016/ j.sbspro.2017.02.025

[5] Ji, X.H. (2016). Study on Art Education in Higher Colleges under the New Media Age. Journal of Hubei Correspondence University, 29(23): 103-104. https://doi.org/10.3969/ j.issn.1671-5918.2016.23.050

[6] Gao, Y. (2019). The current situation and development of painting teaching in Colleges and Universities. Yihai, 2019(6): 124-125. https://doi.org/10.3969/j.issn.1673$\underline{1611.2019 .06 .051}$

[7] Olivier, E., Galand, B., Morin, A.J., Hospel, V. (2020). Need-supportive teaching and student engagement in the classroom: Comparing the additive, synergistic, and global contributions. Learning and Instruction, 71: 101389. https://doi.org/10.1016/j.learninstruc. $\underline{2020.101389}$

[8] Lazarides, R., Watt, H.M., Richardson, P.W. (2020). Teachers' classroom management self-efficacy, perceived classroom management and teaching contexts from beginning until mid-career. Learning and Instruction, 69: 101346. https://doi.org/10.1016/j.learn instruc.2020.101346

[9] Jin, D. (2018). Research on the practice of classroom teaching reform of art education major in Colleges and Universities. Art Panorama, 2018(4): 136-137. https://doi.org/10. 3969/j.issn.1002-2953.2018.04.053

[10] Chen, Y. (2020). Research on the teaching strategies of art education major in Tibetan classes in the mainland. Western China Quality Education, 6(13): 98-100. https://doi. org/10.16681/j.cnki.wcqe.202013044 
[11] Sawyer, R.K. (2017). Teaching creativity in art and design studio classes: A systematic literature review. Educational research review, 22: 99-113. https://doi.org/10.1016/ j.edurev.2017.07.002

[12] Liang, J.C., Li, H. (2016). The Status and Strategies of Arts Teaching of College Art Education in Multi-nation Areas-Taking Hotan Normal School as an Example. Journal of Xinjiang Arts Institute, 35(3): 89-92. https://doi.org/10.3969/j.issn.1671-0908.2016.03.021

[13] Xi, Y.N. (2020). Research on the Current Situation and Strategies of Art Teaching in Colleges and Universities under the Internet Plus Background. Jiaoyu Jiaoxue Luntan, 2020(13): 157-158.

[14] Unver, S., Ergenc, I. Safety risk identification and prioritize of forest logging activities using analytic hierarchy process (AHP). Alexandria Engineering Journal, 60(1): 15911599. https://doi.org/10.1016/j.aej.2020.11.012

[15] Maček, D., Magdalenić, I., Ređep, N.B. (2020). A systematic literature review on the application of multicriteria decision making methods for information security risk assessment. International Journal of Safety and Security Engineering, 10(2): 161-174. https://doi. org/10.18280/ijsse.100202

[16] Yang, Z.H. (2020). Analysis of the impacts of open residential communities on road traffic based on AHP and fuzzy theory. Ingénierie des Systèmes d'Information, 25(2): 183-190. https://doi.org/10.18280/isi.250205

[17] Jorge-García, D., Estruch-Guitart, V. (2020). Economic valuation of ecosystem services by using the analytic hierarchy process and the analytic network process. comparative analysis between both methods in the Albufera Natural Park of València (Spain). International Journal of Design \& Nature and Ecodynamics, 15(1): 1-4. https://doi.org/10.18280/ijdne.150101

[18] Vardi M., Neyestani M., Ghorbanian A. (2019). Supplier selection and order allocation problem modeling with the aim of comparing incremental discounts versus wholesale discounts by using GA and NSGA algorithms, Journal Europeen des Systemes Automatises, 52(1): 23-34. https://doi.org/10.18280/jesa.520104

[19] Kumar, R., Kim, D.S., Jung, K.H. (2019). Enhanced AMBTC based data hiding method using hamming distance and pixel value differencing. Journal of Information Security and Applications, 47: 94-103. https://doi.org/10.1016/j.jisa.2019.04.007

[20] Taheri, R., Ghahramani, M., Javidan, R., Shojafar, M., Pooranian, Z., Conti, M. (2020). Similarity-based Android malware detection using Hamming distance of static binary features. Future Generation Computer Systems, 105: 230-247. https://doi.org/10.1016/ j.future.2019.11.034

[21] Soota, T. (2020). Multi-response optimization of machining parameter for Zircaloy by response surface methodology and grey relation analysis. Materials Today: Proceedings, 21: 1544-1550. https://doi.org/10.1016/j.matpr.2019.11.084

[22] Baranitharan, P., Ramesh, K., Sakthivel, R. (2019). Multi-attribute decision-making approach for Aegle marmelos pyrolysis process using TOPSIS and Grey Relational Analysis: Assessment of engine emissions through novel Infrared thermography. Journal of Cleaner Production, 234: 315-328. https://doi.org/10.1016/j.jclepro.2019.06.188

[23] Uzun, G. (2019). Analysis of grey relational method of the effects on machinability performance on austempered vermicular graphite cast irons. Measurement, 142: 122-130. https://doi.org/10.1016/j.measurement.2019.04.059 
[24] Pandya, V.J., Rathod, P.P. (2020). Optimization of mechanical properties of green composites by gray relational analysis. Materials Today: Proceedings, 27: 19-22. https:// doi.org/10.1016/j.matpr.2019.08.166

[25] Yadav, S.K., Yadav, S.K.S. (2020). Optimization of machining parameters during the ECCDG of inconel 718 using PCA based grey relational analysis. Materials Today: Proceedings. https://doi.org/10.1016/j.matpr.2020.02.557

\section{Author}

Nan Li is alecturer at School of art and design, Huanghuai University. Research interests: Chinese painting, ink painting, figures, landscape. E-mail: gu1991rong@163.com

Article submitted 2021-01-13. Resubmitted 2021-02-23. Final acceptance 2021-02-24. Final version published as submitted by the authors. 